\title{
Changes in abundance and composition of a Caribbean coral reef zooplankton community after 25 years
}

\author{
Allan Carrillo-Baltodano ${ }^{1 *} \&$ Álvaro Morales-Ramírez ${ }^{1,2}$ \\ 1. Escuela de Biología Universidad de Costa Rica,2060 San José, Costa Rica; acarrillobaltodano@clarku.edu. *Current \\ address: Biology Department, Clark University, 950 Main Street, Worcester, MA 01610, USA. \\ 2. Centro de Investigación en Ciencias del Mar y Limnología (CIMAR), Universidad de Costa Rica, San Pedro, 11501- \\ 2060 San José, Costa Rica; alvaro.morales@ucr.ac.cr
}

Received 19-X-2015. Corrected 21-III-2016. Accepted 19-IV-2016.

\begin{abstract}
Coral reef zooplankton represents a key community in coral ecosystems, as they are involved in trophic and biogeochemical dynamics, and recruitment processes. Zooplankton abundance, composition and biomass were surveyed at six stations within the coral reef at Cahuita National Park, Limon, Costa Rica, in order to compare with the only previous study conducted during 1984. Samples were collected monthly (September 2010-August 2011). Seston biomass $\left(0.49-85.87 \mathrm{mg} / \mathrm{m}^{3}\right)$ and total abundance $(1145-112422$ ind./ $\mathrm{m}^{3}$ ) fluctuated among the months and the stations. Higher values of these two variables were found in the rainiest months (November 2010 and May 2011). A total of 38 taxa were identified, of which calanoid copepods abundance dominated year round (66\%), followed by appendicularians (12\%). Zooplankton mean abundance in this survey resulted 20 times higher $\left(13184 \pm 4104 \mathrm{ind} . / \mathrm{m}^{3}\right)$ than in $1984\left(645 \pm 84 \mathrm{ind} . / \mathrm{m}^{3}\right)$. Copepods and appendicularians were the groups that differed the most, relative to the 1984 study, resulting in 63 and 170 times more abundant overall, respectively. An increase in terrestrial runoff and nutrient input during the past 30 years could explain these differences. High abundances of zooplankton may constitute an important food source for coral reef organisms in Cahuita ecosystem. In addition, zooplankton abundances here reported for Cahuita are among the worldwide highest coral reef zooplankton abundances, and further trophic models can help elucidate its role in coral reef resilience in the Caribbean Coast of Central America. Rev. Biol. Trop. 64 (3): 1029-1040. Epub 2016 September 01.
\end{abstract}

Key words: abundance, biomass, Caribbean coast, holoplankton, meroplankton.

Zooplankton accomplishes an important role in the dynamics of coral reef ecosystems (McKinnon, Richardson, Burford, \& Furnas, 2007). They represent the link between primary producers and multiple trophic levels (Alldredge \& King, 2009), participate in biogeochemical cycles (Roman, Furnas, \& Mullin, 1990), and on pelagic and benthic fauna recruitment (Hughes et al, 2000; Grorud-Colvert \& Sponaugle, 2009). Composed of holoplanktic species that form swarms near reef structures (Hammer \& Carleton, 1979); meroplanktic species (early stages of benthic or nektic fauna); and demersal species, which emerge from the benthos and migrate towards the surface during the night (Robichaux, Cohen, Reaka, \& Allen, 1981). In the Caribbean basin, coral reef zooplankton is essential for reef ecosystem functioning (Yoshioka, Owen, \& Pesante, 1985).

However, there is still a gap of information in some parts of the Caribbean region, especially in countries between Belize and Panama. Along the Caribbean coast of Costa Rica, the largest fringing reef is located in Cahuita National Park. Yet, there is a scarcity of surveys focusing on the pelagic realm. Silva-Benavides (1986) found the greatest biomass and abundance of phytoplankton during the rainiest month. As expected, these months report the 
highest input of terrestrial nutrients. In this park, Morales and Murillo (1996) surveyed the abundance and composition of zooplankton monthly in 1984. Peaks of total abundance also coincided with the rainiest months, leading to the assumption that the nutrient input has a strong effect on the zooplankton community of Cahuita through the increase of primary production. Copepods dominated the zooplankton abundance, while fish larvae and crustacean larvae were the principal groups of the meroplankton (Morales \& Murillo, 1996). This study aimed at estimating the seston biomass, abundance and composition of the coral reef zooplankton, and marine invertebrate larvae, at Cahuita National Park after a 25 years gap of zooplankton research.

\section{MATERIAL AND METHODS}

Study site: Cahuita National Park is located on the Southern Caribbean coast of Costa Rica $\left(9^{\circ} 45^{\prime} \mathrm{N}-82^{\circ} 48^{\prime} \mathrm{W}\right)$. The fringing reef consists of a main crest $(5 \mathrm{~km})$ along Punta Cahuita, and two inner crests, one in the Eastern side (Puerto Vargas) and the other in the Western side (Playa Blanca) (Cortés \& Risk,
1985). Small patch reefs and seagrass beds are common in the lagoon. The main current flows in a Northwest to Southeast direction, with eddy formation. In order to compare this research with Morales and Murillo's work (1996), the same four stations (Sts. 1, 2, 3, 4) were selected. In addition, two stations at Playa Blanca were selected to look at the influence of two small rivers inflows: Perezoso (St. 5) and Suárez (St. 6) (Fig. 1). Features of the stations are summarized in table 1.

Environmental features: From September 2010 to August 2011, the salinity (Atago), surface sea temperature (SST) and Secchi depth were measured monthly at each station. Qualitative observations of cloud cover and surge were also obtained. The National Meteorological Institute provided data on precipitation and wind speed and direction (Table 2).

Biomass and abundance: During the year surveyed, two samples of zooplankton were collected monthly from each station, with the use of a Working Party (WP) net (0.47 $\mathrm{m}$ diameter opening and $200 \mu \mathrm{m}$ mesh) for 5 min. Horizontal tows were conducted during

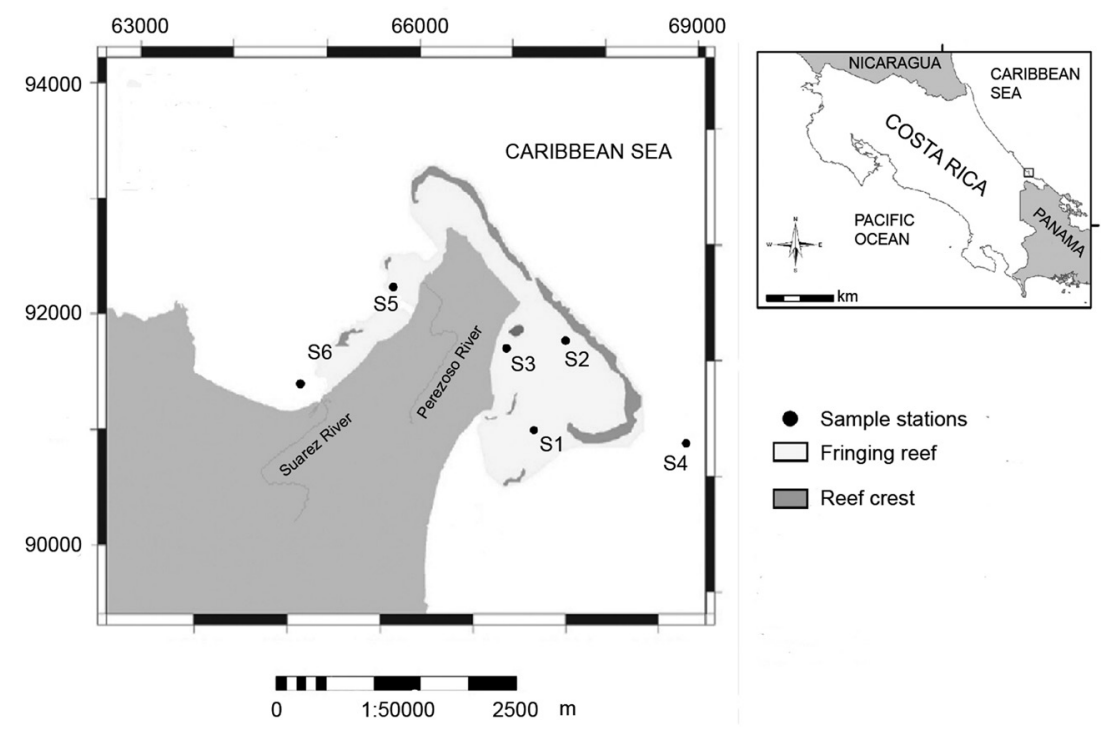

Fig. 1. Stations visited during September 2010-August 2011 at Cahuita National Park, Limón (modified from Fonseca, Salas, \& Cortés, 2006). 
TABLE 1

Morphological description of the stations sampled at Cahuita National Park, Limón, Costa Rica

\begin{tabular}{|c|c|c|c|}
\hline Station & $\begin{array}{l}\text { Range of bottom } \\
\text { depth (m) }\end{array}$ & Characteristics & Source \\
\hline 1 & $4-6$ & $\begin{array}{l}\text { Back reef. Sandy bottom, coral rubble. Small colonies of } \\
\text { Porites porites and Siderastrea siderea. }\end{array}$ & $\begin{array}{l}\text { Morales \& Murillo 1996; } \\
\text { ACB, pers. Obs. }\end{array}$ \\
\hline 2 & $2-3.5$ & $\begin{array}{l}\text { Back reef. Large colonies of Siderastrea siderea and } \\
\text { Monstastrea complanata; benthic algae. }\end{array}$ & $\begin{array}{l}\text { Morales \& Murillo 1996; } \\
\text { ACB, pers. Obs. }\end{array}$ \\
\hline 3 & $1.5-2$ & Back reef. Thalassia testudinum beds. & Morales \& Murillo 1996 \\
\hline 4 & $10-15$ & Fore reef. Sandy and rocky bottom; benthic algae. & Morales \& Murillo 1996 \\
\hline 5 & $5-7.5$ & $\begin{array}{l}\text { Back reef. Thalassia testudinum and Syringodium filiforme } \\
\text { beds; Manicina areolata colonies. }\end{array}$ & $\begin{array}{l}\text { Nielsen-Múñoz \& Cortés } \\
\text { 2008; ACB, pers. Obs. }\end{array}$ \\
\hline 6 & $4-6$ & $\begin{array}{l}\text { Back reef. Sandy bottom; Thalassia testudinum beds; large } \\
\text { number of macroalgae (e.g. Sargassum). }\end{array}$ & $\mathrm{ACB}$, pers. obs. \\
\hline
\end{tabular}

TABLE 2

Monthly mean of physical features during the zooplankton sampling in six stations at Cahuita National Park, Limón, Costa Rica; from September 2010 to August 2011

\begin{tabular}{lcccccc}
\multicolumn{1}{c}{ Month } & Sal $(\mathrm{PSU})$ & Temp $\left({ }^{\circ} \mathrm{C}\right)$ & Secchi Depth $(\mathrm{m})$ & Prec. P.V. $(\mathrm{mm})$ & Prec. Lim $(\mathrm{mm})$ & Wind Speed Lim $(\mathrm{km} / \mathrm{h})$ \\
SET $^{*}$ & 34.2 & 29.3 & 3.6 & 145.2 & 90.1 & 7.4 \\
OCT $^{*}$ & 33.0 & 28.6 & 2.1 & 149.3 & 125.2 & 9.0 \\
NOV $^{*}$ & 35.5 & 28.9 & 3.5 & 372.2 & 592.8 & 8.4 \\
DEC $^{*}$ & 35.7 & 28.9 & 3.5 & 593.4 & 586.4 & 9.4 \\
JAN & 30.5 & 25.9 & 1.2 & 439.9 & 541.3 & 7.3 \\
FEB & 32.2 & 26.9 & 2.3 & 386.1 & 369.7 & 7.8 \\
MAR & 31.0 & 27.0 & 1.4 & 52.8 & 52.9 & 8.0 \\
APR & 31.5 & 25.9 & 1.4 & 184.7 & 222.1 & 8.1 \\
MAY & 32.0 & 27.5 & 3.6 & 360.7 & 406.6 & 8.0 \\
JUN & 29.7 & 29.3 & 5.6 & 208.2 & 190.2 & 8.0 \\
JUL & 31.3 & 29.4 & 2.8 & 212.6 & 140.1 & 7.4 \\
AUG & 32.7 & 29.1 & 3.5 & 35.6 & 62.0 & 7.1 \\
\hline
\end{tabular}

*Months sampled in 2010. PSU: practical salinity units; Prec. P.V.: precipitation at Puerto Vargas; Prec. Lim: precipitation at Limón; Wind Speed Lim: wind speed at Limón.

daytime from a boat at $4 \mathrm{~km} / \mathrm{h}$. A calibrated flow meter (Model 2030R, General Oceanics, Incorporated) was attached to the net for later zooplankton abundance estimation. A buoy and a 2-pound weight were also attached to position the net to approximatly $1 \mathrm{~m}$ depth underwater. Stations were surveyed within $3 \mathrm{~h}$ during a given collection day.

Samples were fixed in a $4 \%$ formalin/sea water solution. In the laboratory, no less than $72 \mathrm{~h}$ later, excessive detritus was removed from the samples using distilled water and $4 \mathrm{~mm}$ and $180 \mu \mathrm{m}$ sieves. A Folsom splitter was used to obtain a subsample (1/4), from which seston dry weight was measured (Beers, 1981). Nakajima, Yoshida, Ross, \& Toda (2010) suggested that zooplankton biomass is overestimated by the dry weight method in coastal ecosystems, due to high amount of phytoplankton and detritus. This is the reason why seston biomass was considered instead of zooplankton biomass for Cahuita. From another subsample, at least 400 organisms were counted and identified following Gasca \& Suárez (1996), Smith and Johnson (1996), and Boltovskoy (1981).

A Canonical Correspondence Analysis was used to determine associations between the physical variables and the abundance of 
zooplankton groups, employing the MultiVariate Statistical Package (Kovach, 2004). Mean biomass $\left(\mathrm{mg} / \mathrm{m}^{3}\right)$ and mean total abundance (ind. $/ \mathrm{m}^{3}$ ) were transformed $(\log \mathrm{x}+$ 1) to compare the stations and months sampled with an ANOVA in $\mathrm{R}$ version 3.1.0 ( $\mathrm{R}$ Core Team, 2014).

A two-way ANOSIM evaluated the statistical differences in the abundance of different groups of zooplankton between months and stations, using PAST (Hammer, Haper, \& Ryan, 2001). A one-way ANOSIM, with Gower distance was conducted to search for differences between Morales and Murillo (1996) and the present study. We selected the Gower distance because of the ordinal nature of some of the abundances reported by Morales and Murillo (1996). We used a MDS to show the differences. Finally, a paired t-test (or Wilcoxon for ordinal abundances) was performed to compare total zooplankton, holozooplankton, merozooplankton, and each zooplankton group's abundance between both studies.

\section{RESULTS}

Environmental conditions associations: SST ranged from 25 to $30{ }^{\circ} \mathrm{C}$ (mean $=28{ }^{\circ} \mathrm{C}$ ) and salinity from 27 to $37 \mathrm{PSU}$. The maximum depth of the Secchi disk was at St. 4, reaching $15 \mathrm{~m}$ in August 2011. Two peaks of precipitation were observed: one between November 2010 and February 2011, and the second one in May 2011. No clear association was found between the environmental variables, the months and stations sampled (Fig. 2A and Fig. B), except for a weak trend in the increment of precipitation in November 2010.

Between the zooplankton groups, the appendicularians showed an association with high values of precipitation, salinity and temperature. Some meroplankton forms like echinoderm or mollusk larvae were associated with wind and surge, the latter two environmental variables were strongly associated (Fig. 2C).
Seston biomass: Seston biomass varied between months (Fig. 3A; ANOVA, P $<0.0001$ ) from $0.49 \mathrm{mg} / \mathrm{m}^{3}$ (August 2011, St. 5) to $85.87 \mathrm{mg} / \mathrm{m}^{3}$ (October 2010, St. 2) with a mean of $10.05 \pm 0.78 \mathrm{mg} / \mathrm{m}^{3}$. Highest seston values were observed for November 2010 and July 2011, whereas August 2011 showed the lowest record. Additionally, we found differences between stations (Fig. 3B; ANOVA, $\mathrm{P}<0.05$ ): St. 1, 2 and 3, as well St. 5 and 6 were very similar to each other, while St. 4 had the lowest biomass value.

Community abundance and composition: Zooplankton total abundance showed temporal and spatial variability, ranging from 1145 ind. $/ \mathrm{m}^{3}$ (February 2011, St. 5) to 112422 ind. $/ \mathrm{m}^{3}$ (November 2010, St.1), with a mean of $12847 \pm 510 \mathrm{ind} . / \mathrm{m}^{3}$. Monthly differences were found (Fig. 4A; ANOVA, $\mathrm{P}<0.0001$ ), with two peaks: the first one in November 2010, that reached a mean abundance of $37640 \pm 44293 \mathrm{ind} . / \mathrm{m}^{3}$, and the second one in May 2011, reaching $42402 \pm 23767$ ind. $/ \mathrm{m}^{3}$. The lowest abundances were recorded in February $2011\left(3082 \pm 1746\right.$ ind. $\left./ \mathrm{m}^{3}\right)$ and August 2011 (4244 \pm 1955 ind. $\left./ \mathrm{m}^{3}\right)$. Between stations the zooplankton abundance was also different (Fig. 4B; ANOVA, $\mathrm{P}<0.05$ ), with St. 1 and 2 possessing the highest abundances, and St. 3 the lowest.

We found 38 taxa, which year-round showed significantly differences (ANOSIM, $\left.\mathrm{r}^{2}=0.48 ; \mathrm{P}<0.0001\right)$. Zooplankton differed among stations (ANOSIM, $\mathrm{r}^{2}=0.44 ; \mathrm{P}<$ $0.0001)$. Copepod abundance $(8431 \pm 8319$ ind. $/ \mathrm{m}^{3}$ ) contributed $65 \%$ of the total zooplankton abundance, with two peaks (November 2010 and May 2011) coinciding with the trends for total zooplankton abundance. Other notable groups include appendicularians and cladocerans which shows similar trends to these recorded in the zooplankton (Fig. 5). Among the meroplankton, mollusk and crustacean larvae (nauplii, mysis, zoea and phyllosoma) showed the highest abundances (Fig. 6). 

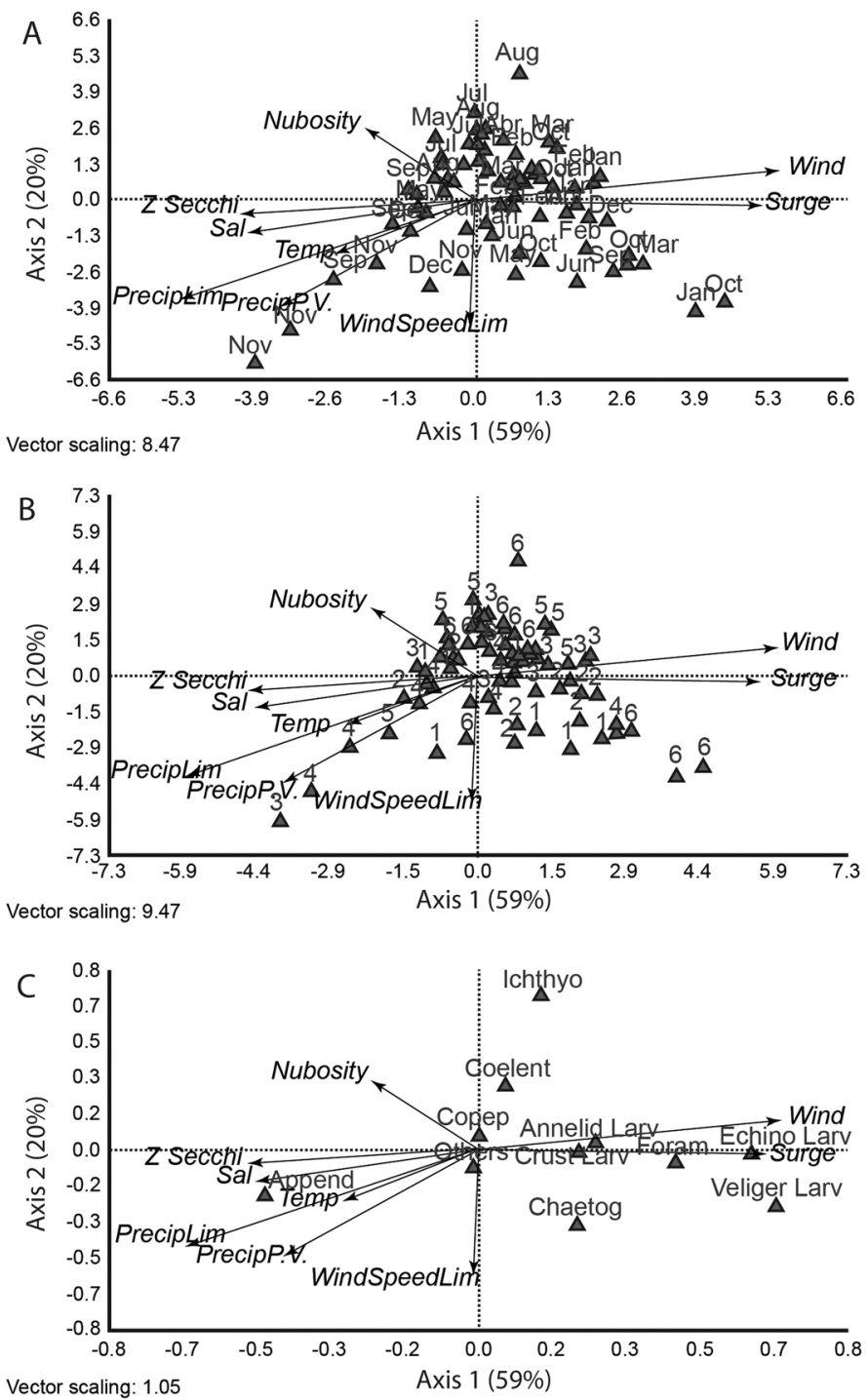

Fig. 2. Canonical correspondence analysis between environmental variables and $(a)$ months, $(b)$ stations and $(c)$ general zooplankton taxa at Cahuita NP, Limón; from September 2010 to August 2011.

This led to a large difference between holoplankton and meroplankton abundance (Fig. 7).

\section{Zooplankton community 25 years later:} Zooplankton abundances recorded in January and November were different than those reported by Morales and Murillo (1996) (ANOSIM, $\left.r^{2}=0.67, \mathrm{P}<0.001\right)$. The mean abundance $\left(645 \pm 84\right.$ vs $13184 \pm 4104$ ind. $\left./ \mathrm{m}^{3}\right)$ was 20 times higher in the present study (Fig. 8), and the MDS evidently showed the difference (Fig. 9). Such differences resulted from the disparity between copepod and appendicularian abundances. These groups were respectively 63 and 170 times more abundant overall, and in November, 170 and 7340 times, in the present 

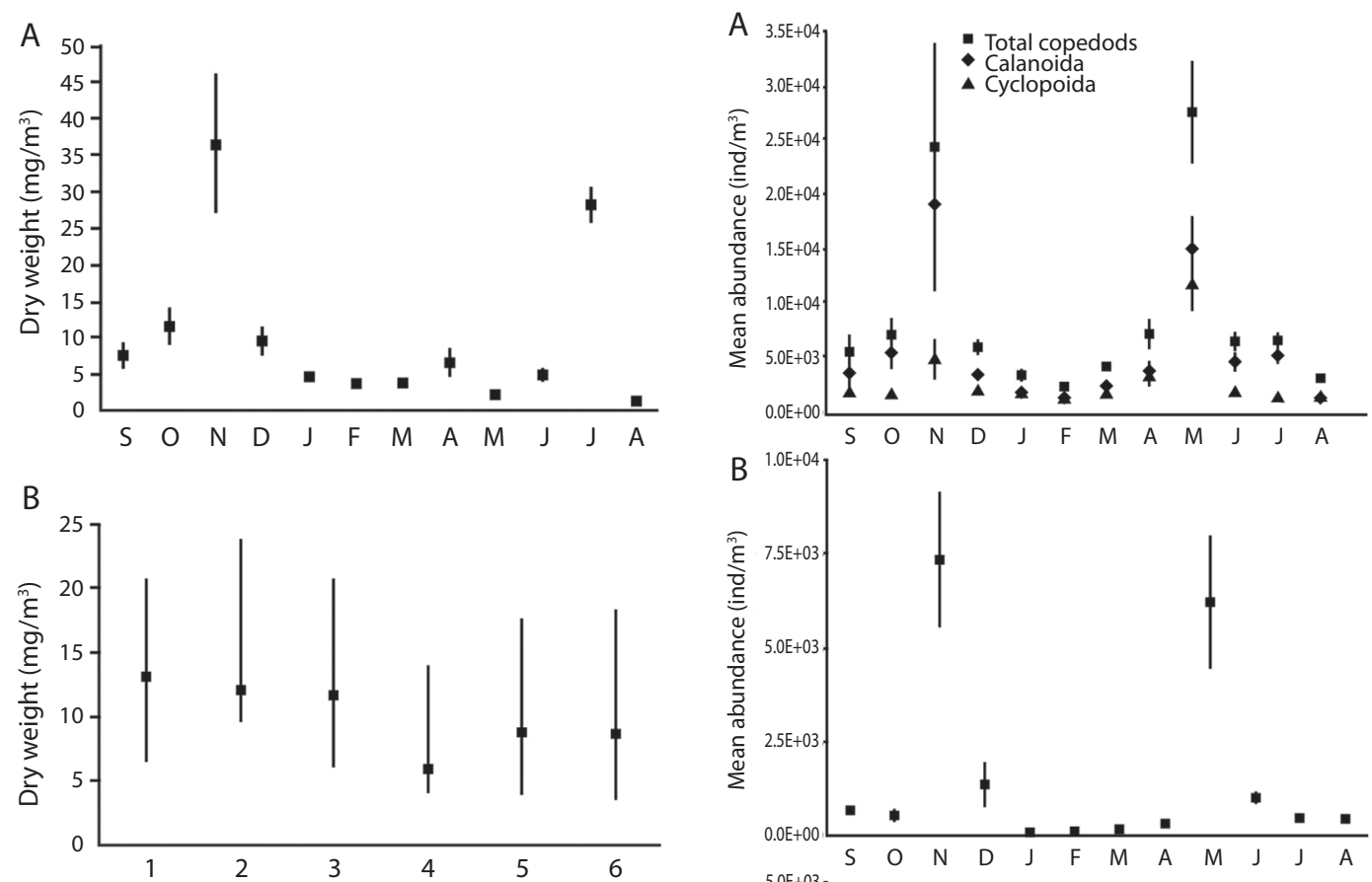

Fig. 3. Mean variation between months $(a)$ and stations $(b)$ of seston biomass at Cahuita NP, Limón; from September 2010 to August 2011. Error bars represent the se.
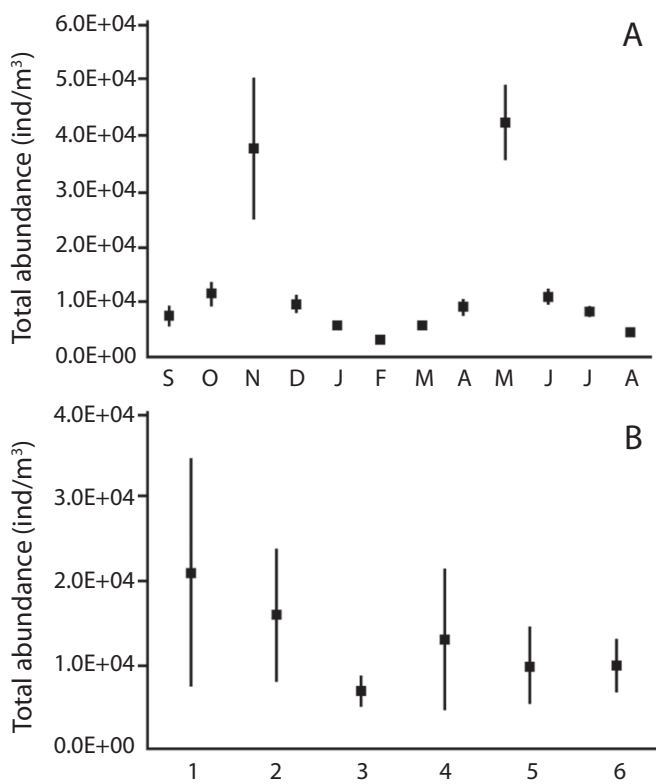

Fig. 4. Mean variation between months $(a)$ and stations (b) of zooplankton abundance at Cahuita NP, Limón; from September 2010 to August 2011. Error bars represent the se.
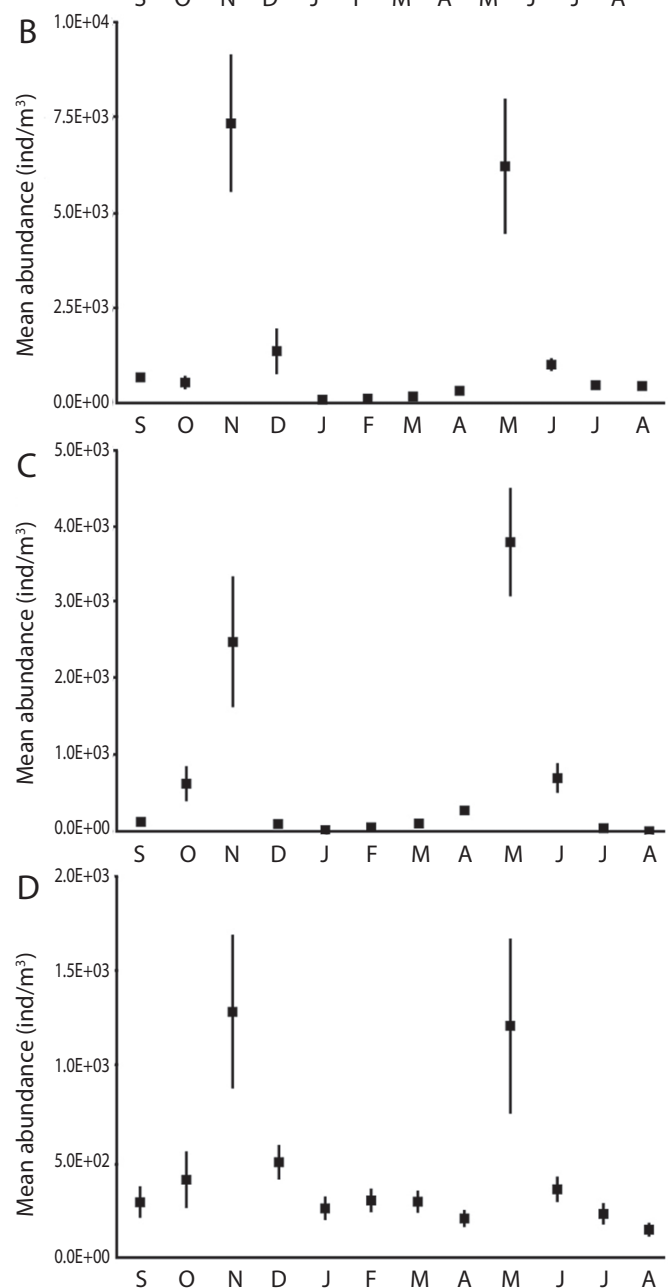

Fig. 5. Mean abundance of the dominant groups of holoplankton (a) copepods, (b) appendicularians, (c) cladocerans and $(d)$ chaetognaths at Cahuita NP, Limón; from September 2010 to August 2011. Error bars represent the se. 

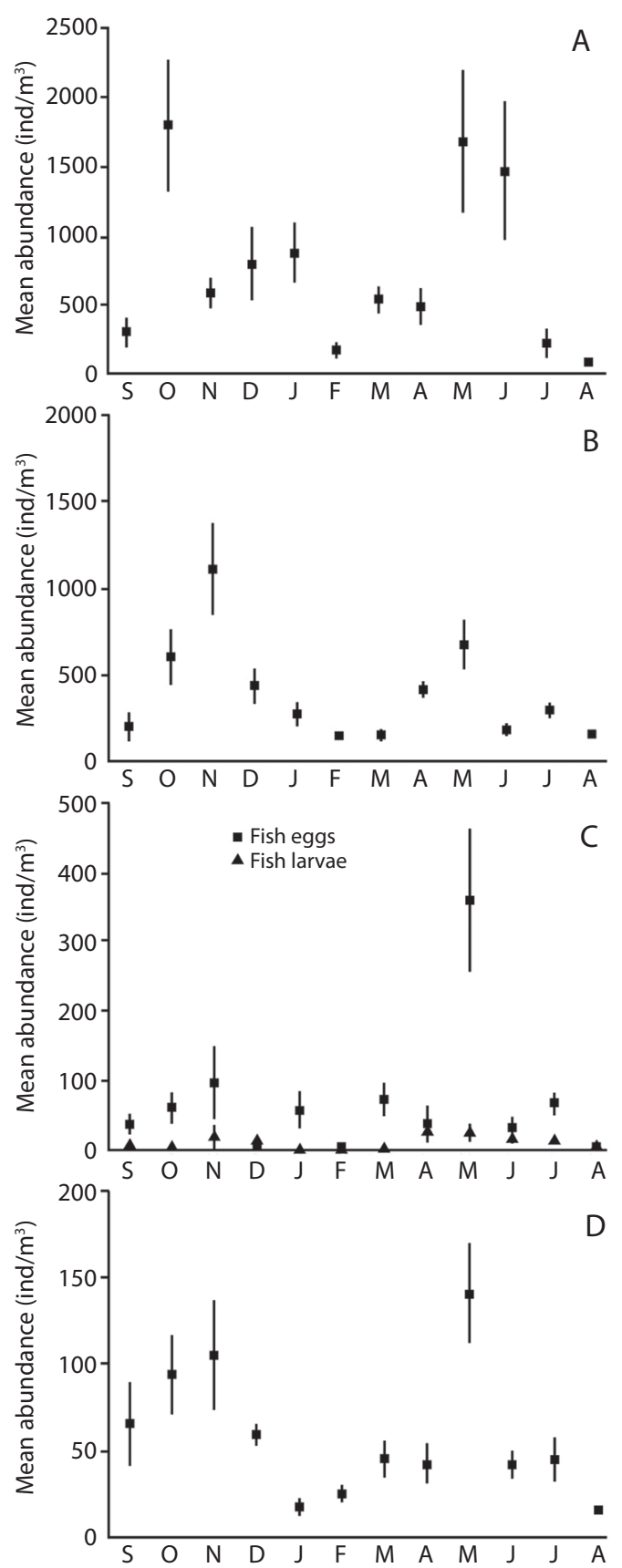

Fig. 6. Mean abundance of the dominant groups of meroplankton $(a)$ mollusk veligers, $(b)$ crustacean larvae, (c) ichthyoplankton and $(d)$ polychaete larvae at Cahuita NP, Limón; from September 2010 to August 2011. Error bars represent the se. study. The rest of the zooplankton groups also showed differences between studies, except for foraminifera, amphipods and icthyoplankton.

Shared stations (St. 1-4) also showed differences, being 29 times more abundant than those recorded by Morales and Murillo (1996) (ANOSIM, $\mathrm{r}^{2}=0.89 ; \mathrm{P}<0.05$; Table 3 ). Higher abundance overall was found in St. 1 (21 192 ind. $\left./ \mathrm{m}^{3}\right)$ and 2 (16 069 ind. $\left./ \mathrm{m}^{3}\right)$. By contrast, in 1984, St. 2 and 4 were more abundant.

TABLE 3

Total abundance of zooplankton (ind. $/ \mathrm{m}^{3}$ ) from the shared stations between Morales and Murillo (1996) and the present study (September 2010-August 2011) at Cahuita NP, Limón

\begin{tabular}{ccc} 
Station & Morales and Murillo (1996) & Present study \\
1 & 1130 & 21192 \\
2 & 3265 & 16069 \\
3 & 1336 & 6926 \\
4 & 1468 & 13262 \\
\hline
\end{tabular}

\section{DISCUSSION}

Precipitation was associated with temperature, salinity and Secchi depth, but not with a particular station or month sampled. We expected that salinity would decrease in St. 5 and St. 6, both at river mouths. However, apparently their runoff does not contribute much to a decrease in either salinity or temperature.

Salinity and Secchi depth values were similar to those reported before (Silva-Benavides, 1986). The highest transparency and salinity recorded in St. 4 (outer crest) indicated the effect of a more oceanic condition. On the other hand, the sediment resuspension near the shoreline produces an input of nutrients to the water column, resulting in more food for planktic primary producers, but more turbidity for benthic primary producers.

We present the first values of seston biomass for Cahuita's reef. Few seston biomass records for the Grand Caribbean are primarily available from Mexico. The seston values 


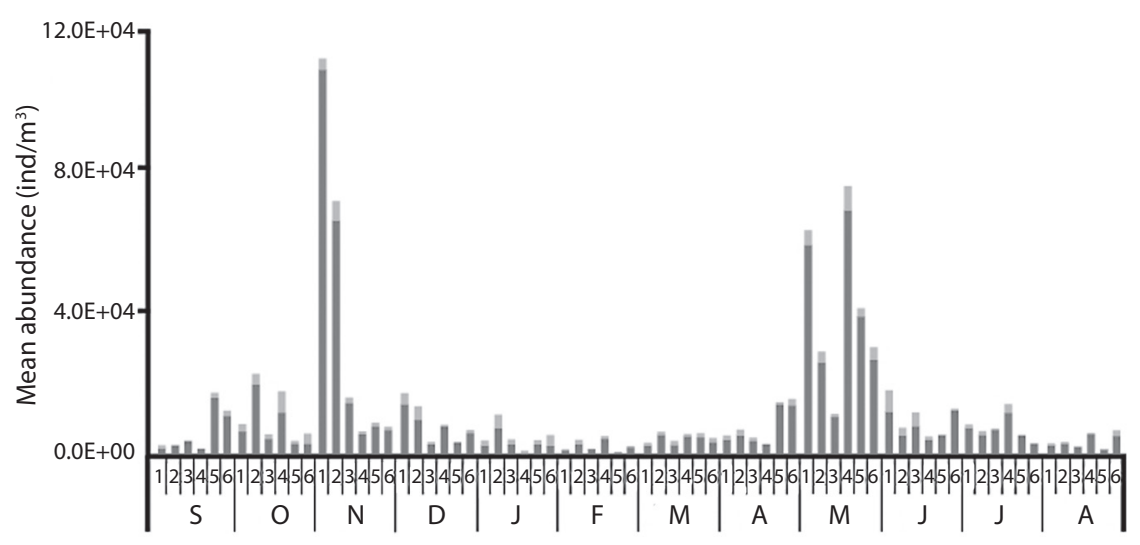

Fig. 7. Total abundance of holoplankton (dark gray) and meroplankton (light gray) in six stations at Cahuita NP; from September 2010 to August 2011.

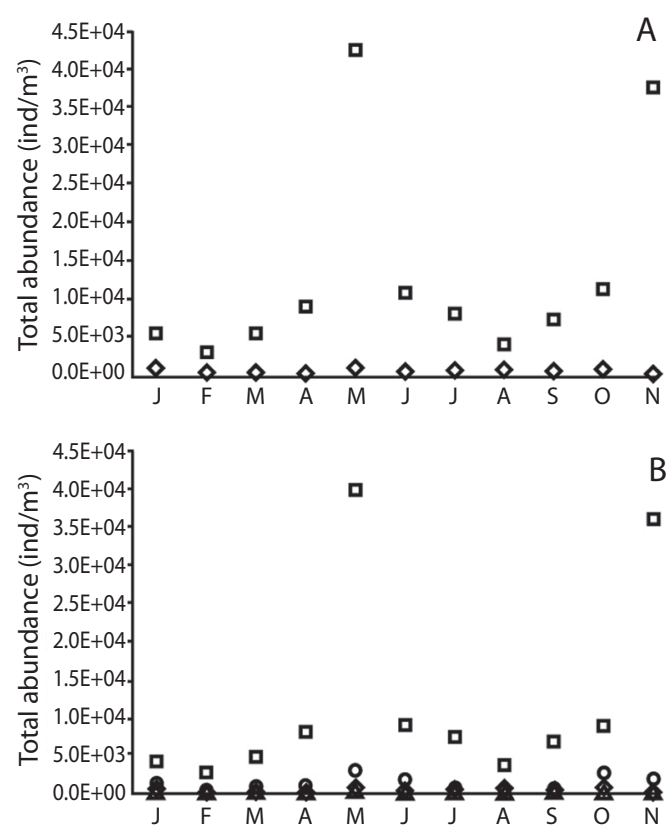

Fig. 8. (a) Total abundance of total zooplankton (squares: present study; diamonds: Morales \& Murillo (1996)); (b) total abundance of holozooplankton (squares: present study; diamonds: Morales \& Murillo (1996)) and merozooplankton (circles: present study; triangles: Morales \& Murillo (1996)) of the months shared between Morales \& Murillo (1996) and the present study at Cahuita NP, Limón.
A recorded in Cahuita $\left(0.49-85.87 \mathrm{mg} / \mathrm{m}^{3}\right)$ are lower than those recorded in Mahahual (14.79$\left.143.26 \mathrm{mg} / \mathrm{m}^{3}\right)$ by Castellanos and Suárez (1997). On the North-side of Quintana Roo, a higher value $\left(75 \mathrm{mg} / \mathrm{m}^{3}\right)$ was found in a coastal lagoon system compared to the reef (36 $\mathrm{mg} / \mathrm{m}^{3}$ ), but the latter was higher than in the ocean waters $\left(34 \mathrm{mg} / \mathrm{m}^{3}\right)$. This difference was attributed to higher nutrient resuspension rates (Álvarez-Cardena, Ordóñez-López, ValdésLozano, Almaral-Mendívil, \& Uicab-Sabido, 2007). A relationship between higher concentrations of nitrates, chlorophyll $a$ and zooplankton biomass, has been found in other Caribbean reefs like Bocas del Toro and Laguna Chiriquí in Panama (D'Croz, del Rosario, \& Góndola, 2005) and Puerto Rico (Yoshioka et al., 1985).

The mean average zooplankton abundance recorded in this study $\left(12847 \pm 510 \mathrm{ind} . / \mathrm{m}^{3}\right)$ exceeded the obtained values of other surveys in the Caribbean. For instance, those in Quintana Roo, México (8 808 ind. $/ \mathrm{m}^{3}$ ) (ÁlvarezCardena et al., 2007), Mahahual, México (64 ind. $\left./ \mathrm{m}^{3}\right)$ (Castellanos \& Suárez, 1997), and Jamaica (1317-3940 ind. $/ \mathrm{m}^{3}$ ) (Webber, Roff, Chisholm, \& Clarke, 1996). Calanoid copepods dominated the Cahuita zooplankton community, 


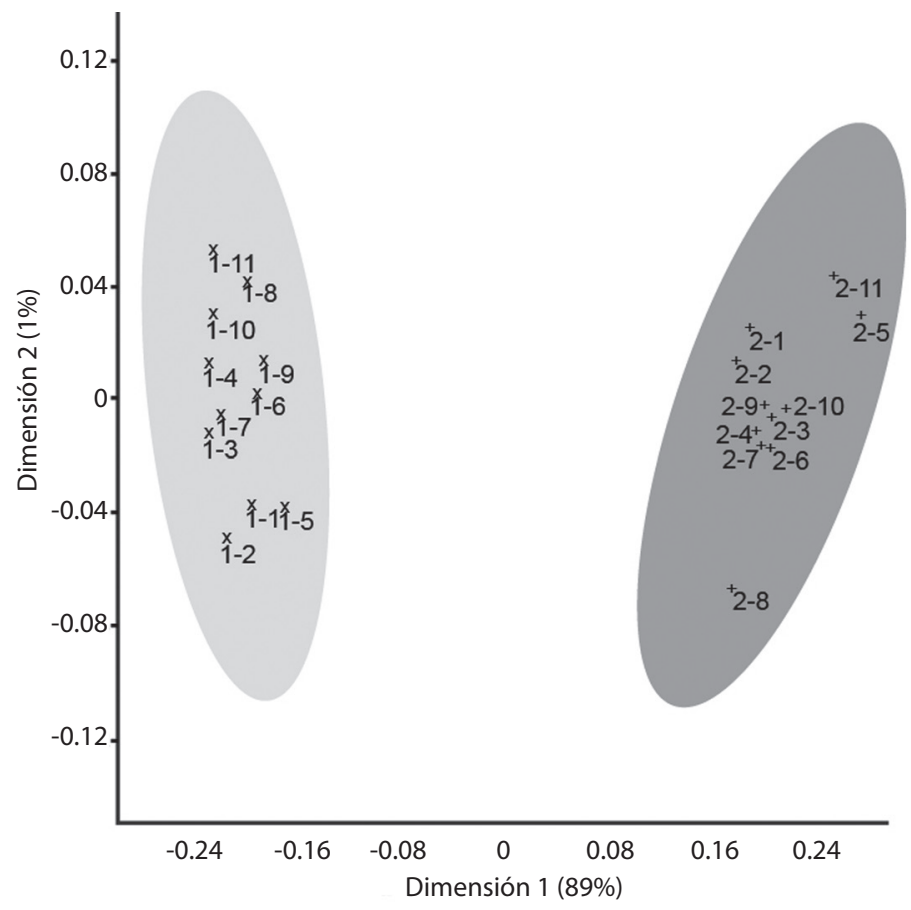

Fig. 9. MDS using Gower's distance among general zooplankton taxa and the months and the stations shared between Morales \& Murillo (1996) and the present study. Cahuita NP, Limón. Morales \& Murillo (1996) data set represented by a number " 1 " in light gray and the present study represented by a number "2" in dark gray. Numbers after hyphen represents the month shared: from January (1) to November (11).

as they do in the majority of the marine ecosystems (Hulsemann, 1996). Calanoids were more abundant in November 2010 (St. 1 and St. 2), while cyclopoids were more abundant in May 2011 (St. 1 and St. 4). For instance, in Jamaica, Ohlhorst (1985) demonstrated that the spatiotemporal variability of zooplankton is mainly the product of Oithona colcarva swarming.

Other groups like appendicularians and cladocerans contributed strongly to the abundance of the zooplankton community. Because of high growth rates, the appendicularian Oikopleura longicauda can surpass copepod production (Hopcroft \& Roff, 1998). Also, the efficient grazing characteristics of the cladoceran Penilia avirostris enable it to achieve abundances of up to 2500 ind. $/ \mathrm{m}^{3}$ (Rose, Roff, \& Hopcroft, 2004).

Mollusk larvae dominated the meroplankton, with values higher than those reported from Mexico (Oliva-Rivera \& de Jesús-Navarrete,
2000), where abundance peaks were associated with the rainy season and higher sea temperature. Morales and Murillo (1996) found the same dominance, but in the present study, we found no relationship between larval abundance and precipitation or temperature.

In addition to biomass, sediment resuspension has been correlated with high abundances of zooplankters in the Nichupte lagoon system (Mexico) (Álvarez-Cardena et al., 2007) and in the Great Barrier Reef (McKinnon et al., 2007). We found the highest abundances in Cahuita, near the shoreline of Puerto Vargas (St. 1 and 2), where previously Roder, Cortés, Jiménez and Lara (2009) reported high values of total suspended matter.

The higher total abundance in the present study, relative to the one documented by Morales and Murillo (1996), is caused by the holoplanktic groups. Copepod abundance was 32 times higher in the present study than 
in 1984. This is an underestimate of copepod abundance, as very abundant swarms of Oithona and Oncea are usually predominant in ocean waters, but are not retained by $>200$ $\mu \mathrm{m}$ nets (Gallienne \& Robins, 2001). Noticeably, Morales and Murillo (1996) used a 280 $\mu \mathrm{m}$ mesh size net, discriminating smaller components of the zooplankton that could explain such large differences. Previously, we reported new records of copepods found in the study (Morales-Ramírez, Suárez-Morales, CorralesUgalde, \& Esquivel-Garrote, 2014), plus the description of two new species of monstrilloid copepods: Monstrillopsis cahuitae SuárezMorales, Carrillo and Morales-Ramírez, 2013 and Cymbasoma alvaroi Suárez-Morales \& Carrillo, 2013 (Suárez-Morales, Carrillo, \& Morales-Ramírez, 2013). Following the same trend, appendicularian and mollusk larvae (meroplankton) abundance was also too low in the past study relative to our current measures.

What are the causes of this divergence in the total and particular abundance of zooplankters between both studies? As mentioned before, the resuspended sediments have been correlated with peaks of biomass and abundance (Álvarez-Cardena et al., 2007). In Cahuita, Roder et al. (2009) found four times more total suspended material in 2004 and 2005 than Cortés and Risk (1985) did in the 1980's. In addition, we found the highest concentrations in Puerto Vargas site, which coincides with peaks of abundance and biomass.

Cortés and Risk (1985) demonstrated that terrestrial runoff from the La Estrella and Banano Rivers adversely affects the health of the reef at Cahuita. In recent years, several land-use changes could be the responsible for a larger discharge of nutrients and silt in those rivers (Mora-Cordero \& Chavarría, 2009).

Moreover, the 1982-1983 ENSO could have triggered certain anomalies in the Caribbean Sea and the Equatorial Atlantic Ocean (González et al., 2000). On the Pacific coast of Costa Rica, Quesada-Alpízar and MoralesRamírez (2006) found a lower zooplankton abundance and biomass during the 1997 ENSO. González et al. (2000) reported an increase in the wind speed, precipitation and surge in the Caribbean coast of Mexico. Hence, these effects might be expected to produce an increase in the zooplankton abundance, rather than the decrease seen in Cahuita. This leads us to think that the 1982-1983 ENSO cannot explain the low abundances reported by Morales and Murillo (1996).

Most of the coral reefs are composed of sessile benthic organisms with a planktic larval phase important for dispersion, spatial distribution stabilization and gene flow (Poulin, Boletzky, \& Féral, 2001). At Cahuita, the meroplankton does not exceed the abundance and diversity of the holoplankton. However, among the essential components in a coral reef, a diverse range of larval forms were found. We also found a high diversity in polychaete larvae and the occurrence of lophophorate larvae. Cahuita seems to have a high availability of larvae, and hence, of possible recruits for the reef.

The coral reef in Cahuita is only an example of the degradation that coral reefs have suffered over the past 30 years (Cortés et al., 2010). Mostly siltation has affected the amount of light available for photosynthesis and also had smothered the living corals, leading to a low growth and low development. However, the high abundance of zooplankton found in this study indicates that nutrient input and zooplankton recruitment are important sources that enable the permanency and survival of corals and reef fauna. Studies of feeding dynamics and elaboration of trophic models are necessary to elucidate the role that zooplankton can have in coral reef resilience, not only in Cahuita National Park but for the entire Caribbean coast of Central America.

\section{ACKNOWLEDGMENTS}

We thank Jorge Cortés, Gerardo Umaña and Mario Espinoza for their valuable comments; Jeffrey Sibaja for statistical advice. Thanks for field assistance go to: Margarita Loría, Victoria Bogantes, Aldo Farah, Andrés Quesada, Carolina Salas, Ana Beatriz Hernández, Darha Solano, Astrid Sánchez and the 
boat captain Marvin Mayrena. All sample collections were carried out with the permission from La Amistad-Caribe Conservation Area and Cahuita National Park administration.

\section{RESUMEN}

Cambios en abundancia y composición de una comunidad de zooplancton arrecifal en el Caribe 25 años después. El grupo de zooplancton representa una comunidad clave en los arrecifes de coral. Está involucrado en dinámicas tróficas y biogeoquímicas, y en procesos de reclutamiento. La abundancia, composición y biomasa del zooplancton fueron estudiadas en seis estaciones dentro del arrecife coralino del Parque Nacional Cahuita, para compararlas con el único estudio realizado durante 1984. Las muestras se recolectaron mensualmente (Septiembre 2010-Agosto 2011). La biomasa del seston (0.49-85.87 $\mathrm{mg} / \mathrm{m}^{3}$ ) y la abundancia total (1 $\left.145-112422 \mathrm{ind} . / \mathrm{m}^{3}\right)$ fluctuaron entre meses y estaciones. Los valores más altos se encontraron durante los meses más lluviosos (Noviembre 2010 y Mayo 2011). Treinta y ocho taxones fueron identificados, copépodos calanoidos $(66 \%)$ y apendicularias (12\%) dominaron la abundancia durante todo el año. La abundancia promedio en este estudio fue 20 veces más alta (13 $184 \pm 4104$ ind. $\left./ \mathrm{m}^{3}\right)$ que en $1984\left(645 \pm 84 \mathrm{ind} . / \mathrm{m}^{3}\right)$. Copépodos y apendicularias fueron los grupos con mayor discrepancia con respecto al estudio de 1984. Un aumento en la descarga de nutrientes de origen terrestre, podría explicar estas grandes diferencias. Abundancias tan altas de zooplancton podrían constituir una importante fuente de alimento para los organismos del arrecife en Cahuita. Las abundancias aquí reportadas colocan al arrecife de Cahuita entre los arrecifes de coral con mayor abundancia de zooplancton en el mundo y estudios futuros en redes tróficas podrían elucidar el papel de esta comunidad en procesos de resiliencia en los arrecifes del Caribe centroamericano.

Palabras clave: abundancia, biomasa, costa Caribeña, holoplancton, meroplancton.

\section{REFERENCES}

Alldredge, A. L., \& King, J. M. (2009). Near-surface enrichment of zooplankton over a shallow back reef: implication for coral reef food webs. Coral Reefs, 28, 895-908.

Álvarez-Cardena, J. N., Ordóñez-López, U., Valdés-Lozano, D., Almaral-Mendívil, A. R., \& Uicab-Sabido, A. (2007). Estudio anual del zooplancton: composición, abundancia, biomasa e hidrología del norte de Quintana Roo, mar Caribe de México. Revista Mexicana de Biodiversidad, 78, 421-430.
Beers, J. R. (1981). Determinación de la biomasa del zooplancton. In D. Boltovskoy (Ed.), Atlas del zooplancton marino del Atlántico Occidental y métodos de trabajo con el zooplancton marino (pp. 133-142). Leiden: Backhuy Publishers.

Boltovskoy, D. (1981). Atlas del zooplancton marino del Atlántico Occidental y métodos de trabajo con el zooplancton marino. Leiden: Backhuy Publishers.

Castellanos, I. A., \& Suárez-Morales, E. (1997). Observaciones sobre el zooplancton de la zona arrecifal de Mahahual, Quintana Roo (Mar Caribe mexicano). Anales del Instituto de Biología. Serie Zoología, 68, 237-252.

Cortés, J., Fonseca, A. C., Nivia-Ruiz, J., Nielsen-Muñoz, V., Samper-Villareal, J., Salas, E., Martínez, S., \& Zamora-Trejos, P. (2010). Monitoring coral reefs, seagrasses and mangroves in Costa Rica (CARICOMP). Revista de Biología Tropical, 58, 1-22.

Cortés, J., \& Risk, M. J. (1985). A reef under siltation stress: Cahuita, Costa Rica. Bulletin of Marine Science, 36, 339-356.

D’Croz, L., del Rosario, J. B., \& Góndola, P. (2005). The effect of fresh water runoff on the distribution of dissolved inorganic nutrients and plankton in the Bocas del Toro archipiélago, Caribbean Panama. Caribbean Journal of Science, 41, 414-429.

Fonseca, A. C., Salas, E., \& Cortés, J. (2006). Monitoreo del arrecife coralino Meager Shoal, Parque Nacional Cahuita, Costa Rica (sitio CARICOMP). Revista de Biología Tropical, 54, 755-763.

Gasca, R., \& Suárez, E. 1996. Introducción al estudio del zooplancton marino. México: El Colegio de la Frontera Sur (ECOSUR)/CONACYT.

Gallienne, C. P., \& Robins, D. B. (2001). Is Oithona the most important copepod in the world's oceans? Journal of Plankton Research, 23, 1421-1432.

González, N., M., Muller-Karger, F. E., Estrada, S. C., de los Reyes, R. P., del Rio, I. V., Pérez, P. C., \& Arenal, I. M. (2000). Near-surface phytoplankton distribution in the Western Intra-Americas Sea: the influence of El Niño and weather events. Journal of Geophysical Research, 105, 14029-14043.

Grorud-Colvert, K., \& Sponaugle, S. (2009). Larval supply and juvenile recruitment of coral reef fishes to marine reserves and non-reserves of the upper Florida Keys, USA. Marine Biology, 156, 277-288.

Hammer, Ø., Harper, D. A., \& Ryan, P. D. (2001). PAST: Paleontological Statistics software package for education and data analysis. Paleontologica Electronica, 4, 1-9. 
Hammer, W. M., \& Carleton, J. H. (1979). Copepod swarms: attributes and role in coral reef ecosystems. Limnology and Oceanography, 24, 1-14.

Hopcroft, R. R., \& Roff, J. C. (1998). Production of tropical larvaceans in Kingston Harbour, Jamaica: are we ignoring an important secondary producer? Journal of Plankton Research, 20, 557-569.

Hughes, T. P., Baird, A. H., Dinsdale, E. A., Moltschaniwskyj, N. A., Pratchett, M. S., Tanner, J. E., \& Willis, B. L. (2000). Supply-side ecology works both ways: the link between benthic adults, fecundity, and larval recruits. Ecology, 81, 2241-2249.

Hulsemann, K. (1996). Copepoda. En R. Gasca \& E. Suárez (Eds.), Introducción al estudio del zooplancton marino (pp. 249-295). México: El Colegio de la Frontera Sur (ECOSUR)/CONACYT.

Kovach Computer Services. (2004). Multi Variate Statistical Package (MVSP Version 3.13I). Retrieved from: http://www.kovcomp.co.uk/mvsp/

McKinnon, A. D., Richardson, A. J., Burford, M. A., \& Furnas, M. J. (2007). Vulnerability of Great Barrier Reef plankton to climate change. In J. E. Johnson, \& P. A. Marshall (Eds.), Climate Change and the Great Barrier Reef (pp. 121-152). Townsville, Australia: Great Barrier Reef Marine Park Authority.

Mora-Cordero, C., \& Chavaría, J. B. (2009). Factores que afectan la cuenca del río La Estrella y recomendaciones para la gestión ambiental en su zona costera (Caribe de Costa Rica). Revista de Biología Tropical, 56, 191-203.

Morales, A., \& Murillo, M. M. (1996). Distribution, abundance and composition of coral reef zooplankton, Cahuita National Park, Limon, Costa Rica. Revista de Biología Tropical, 44, 619-630.

Morales-Ramírez, Á., Suárez-Morales, E., Corrales-Ugalde, M., \& Garrote, O. E. (2014). Diversity of the freeliving marine and freshwater Copepoda (Crustacea) in Costa Rica: a review. ZooKeys, 457, 15-33.

Nakajima, R., Yoshida, T., Ross, B. H., \& Toda, T. (2010) High detritus/phytoplankton content in net-plankton samples from coral reef water: source of over-estimation in zooplankton biomass by measuring seston weight. Plankton \& Benthos Research, 5, 69-73.

Nielsen-Muñoz, V., \& Cortés, J. (2008). Abundancia, biomasa y floración de Thalassia testudinum (Hydrocharitaceae) en el Caribe de Costa Rica. Revista de Biología Tropical, 56, 175-189.

Ohlhorst, S. L. (1985). Reef zooplankton collected along a depth gradient at Discovery Bay, Jamaica. The Ecology of Coral Reefs, 3, 101-116.

Oliva-Rivera, J., \& de Jesús-Navarrete, A. (2000). Composición, distribución y abundancia de larvas de moluscos gastrópodos en el sur de Quintana Roo, México y norte de Belice. Revista de Biología Tropical, 48, 777-783.

Poulin, E., Boletzky, S., \& Féral, J. P. (2001). Combined ecological factors permit classification of developmental patterns in benthic marine invertebrates: a discussion note. Journal of Experimental Marine Biology and Ecology, 257, 109-115.

Quesada-Alpízar, M., \& Morales-Ramírez, A. (2006). Posible efecto de El Niño en el zooplancton no gelatinoso del Golfo Dulce, Pacífico de Costa Rica, 1997-1998. Revista de Biología Tropical, 54, 225-240.

R Core Team (2014). $R$ : A language and environment for statistical computing. Vienna, Austria: R Foundation for Statistical Computing.

Robichaux, D. M., Cohen, A. C., Reaka, M. L., \& Allen, D. (1981). Experiments with zooplankton on coral reefs, or will the real demersal plankton please come up? Marine Ecology Pubblicazioni della Stazione Zoologica di Napoli I, 2, 77-94.

Roder, C., Cortés, J., Jiménez, C., \& Lara, R. (2009). Riverine input of particulate material and inorganic nutrients to a coastal reef ecosystem at the Caribbean coast of Costa Rica. Marine Pollution Bulletin, 58, 1937-1943.

Roman, M. R., Furnas, M. J., \& Mullin, M. M. (1990). Zooplankton abundance and grazing at Davies Reef, Great Barrier Reef, Australia. Marine Biology, 105, 73-82.

Rose, K., Roff, J. C., \& Hopcroft, R. R. (2004). Production of Penilia avirostris in Kingston Harbour, Jamaica. Journal Plankton Research, 26, 605-615.

Silva-Benavides, M. (1986). Productividad primaria, biomasa del fitoplancton y la relación con parámetros fisico-químicos en el arrecife coralino del Parque Nacional Cahuita (Tesis de licenciatura). Universidad de Costa Rica, Costa Rica.

Suárez-Morales, E., Carrillo, A., \& Morales-Ramírez, A. (2013) Report on some Monstrilloids (Crustacea, Copepoda) from a reef area off the Caribbean coast of Costa Rica, Central America with descriptions of two new species. Journal of Natural History, 47, 619-638.

Smith, D. L., \& Johnson, K. B. (1996). A guide to marine coastal plankton and marine invertebrate larvae. Iowa: Kendall Hunt Pub. Co.

Webber, M. K., Roff, J. C., Chisholm, L. A., \& Clarke, C. (1996). Zooplankton distributions and community structure in an area of the south coast shelf of Jamaica. Bulletin of Marine Science, 59, 259-270.

Yoshioka, P. M., Owen, G. P., \& Pesante, D. (1985). Spatial and temporal variations in Caribbean zooplankton near Puerto Rico. Journal of Plankton Research, 7, 733-751. 